\title{
A comparative analysis of lung function and spirometry parameters in genotype-controlled natives living at low and high altitude
}

Esteban Ortiz-Prado ( $\nabla$ e.ortizprado@gmail.com )

OneHealth Global Research Group, Universidad de las Americas

\section{Sebastián Encalada}

OneHealth Global Research Group, Universidad de las Americas

\section{Johanna Mosquera}

OneHealth Global Research Group, Universidad de las Americas

Katherine Simbaña-Rivera

OneHealth Global Research Group, Universidad de las Americas

\section{Lenin Gomez-Barreno}

OneHealth Global Research Group, Universidad de las Americas

\section{Diego Duta}

Limoncocha Community Health Unit, Limoncocha, Ecuador

\section{Israel Ochoa}

Oyacachi Community Health Unit, Oyacachi, Ecuador

Juan S. Izquierdo-Condoy

OneHealth Global Research Group, Universidad de las Americas

\section{Eduardo Vasconez}

OneHealth Global Research Group, Universidad de las Americas

\section{German Burgos}

Faculty of Medicine, universidad de las Americas

\section{Manuel Calvopiña}

OneHealth Global Research Group, Universidad de las Americas

\section{Gines Viscor}

Department of Cell Biology, Physiology and Immunology, Universidad de Barcelona, Barcelona, Spain

\section{Research Article}

Keywords: Limoncocha, Oyacachi, Kichwas, spirometry, pulmonary function, high altitude physiology

Posted Date: September 17th, 2021

DOI: https://doi.org/10.21203/rs.3.rs-900188/v1 
License: (9) (i) This work is licensed under a Creative Commons Attribution 4.0 International License. Read Full License

Version of Record: A version of this preprint was published at BMC Pulmonary Medicine on March 21st, 2022. See the published version at https://doi.org/10.1186/s12890-022-01889-0. 


\section{Abstract}

\section{Background}

The reference values for lung function are associated to anatomical and lung morphology parameters, but anthropometry it is not the only influencing factor: altitude and genetics are two important agents affecting respiratory physiology. Altitude and its influence on respiratory function has been studied independently of genetics, considering early and long-term acclimatization.

Objective

The objective of this study is to evaluate lung function through a spirometry study in autochthonous Kichwas permanently living at low and high-altitude.

Methodology

A cross-sectional study of spirometry differences between genetically matched lowland Kichwas from Limoncocha $(230 \mathrm{~m})$ at Amazonian basin and high-altitude Kichwas from Oyacachi $(3,180 \mathrm{~m})$ in Andean highlands. Chi-square method was used to analyze association or independence of categorical variables, while Student's t test was applied to comparison of means within quantitative variables. ANOVA, or in the case that the variables didn't meet the criteria of normality, Kruskal Wallis test were used to compare more than two groups.

Results

People from Oyacachi (high altitude) showed a higher predicted values than those from Limonocha (low altitude). The FVC and the FEV 1 were significantly greater among highlanders than lowlanders ( $p$ value $<$ 0.001). The $\mathrm{FEV}_{1} / \mathrm{FVC}$ was significantly higher among lowlanders than highlanders for men and women. $\mathrm{A}$ restrictive pattern was found in $12.9 \%$ of the participants.

\section{Conclusion}

Residents of Oyacachi had greater lung capacity than their peers from Limoncocha, a finding physiologically plausible according to published literature. When analyzing the spirometric patterns obtained in these populations, it was evident that no person had an obstructive pattern, while on the other hand, the restrictive pattern appeared in Limoncocha and Oyacachi populations in $12.9 \%$ although it is clear that there is a predominance of this in the individuals belonging to Limoncocha.

\section{Introduction}

Worldwide, more than 140 million people reside above 2,500 meters [1]. Studying high-altitude dwellers is essential to understand the environmental, physiological and genetic factors that are linked to the incidence and prevalence of different maladies in these populations [2]. Acute and chronic exposure to high altitude has a variety of effects on human physiology and diseases occurrence [3]. Barometric pressure decreases exponentially with increasing altitude[4]. Consequently, the partial pressure of oxygen also decreases, despite 
the composition of gases in the atmosphere remains unaltered. The physiological consequences of this reduction in oxygen availability begin to be noticeable, even at rest, from an altitude of 2,500 $\mathrm{m}$ [4].

Living at high altitudes requires different genetical, molecular, physiological and anatomical adaptive mechanisms to counteract the effects of acute or chronic hypoxia[5, 6]. Those mechanisms or changes that attempt to improve the ventilatory and cardiovascular responses are likely to be the most significant[7, 8]. Anatomical changes including chest depth and chest width have been described among high altitude natives[9-12]. Improved hypoxic ventilatory responses (HVR) and differences in ventilations rates have also been described among high altitude population[13-15]. All these changes in general translate into a better ventilation and improved spirometric values when compared with individuals living at sea level[16, 17]. Among healthy people living at different altitudes, it has been shown that lung capacity is generally higher in individuals living at high altitudes than in those living at sea level[18]. Pulmonary function seems to relate to the time that elapses between exposure to hypoxia and the performance of the spirometry. For instance, in non-adapted subjects who are acutely exposed to high altitudes, lung capacity decreases temporarily. CompteTorrero et al., reported that espiratory volume during the first second of forced expiration $\left(\mathrm{FEV}_{1}\right)$ was reduced by $12.3 \%( \pm 5.7 \%)$ and the mean Forced vital capacity (FVC) by $7.6 \%( \pm 6.7 \%)$ among 8 mountaineers who ascended to $3,000 \mathrm{~m}[19]$. They also found that the FEV1/FVC ratio, also called Tiffeneau-Pinelli index remained normal[19]. Another short term exposure analysis performed by Cremona et al. at 1,200m and $4,559 \mathrm{~m}$ of showed that the FVC did not present significant variations but the $\mathrm{FEV}_{1}$ increased by $2 \%$ among the high altitude group [20].

In terms of long-term exposure, several studies show people who live at high altitudes have significantly higher spirometric values than those who live at sea level[17]. According to Weitz et al., people who reside above $3,200 \mathrm{~m}$ have greater $\mathrm{FVC}$ and $\mathrm{FEV}_{1}$ parameters than those low altitude dwellers [21]. Similarly, Brutsaert et al., compared the results of two Bolivian populations located at $3,600 \mathrm{~m}$ and $420 \mathrm{~m}$ of elevation [10]. They found greater FVC and $\mathrm{FEV}_{1}$ volumes when comparted to the subjects located at a lower elevations [10].

In this sense, in order to add important insights in terms of physiological differences between low and high altitude dwellers, we have performed a comparative analysis between a unique Andean genotyped-controlled indigenous population that reside at two different locations in Ecuador. The Kiwcha natives from Limoncocha that lives at $230 \mathrm{~m}$ of elevation were invited to participate as the low altitude control group, while the Oyacachi native population that lives at $3,800 \mathrm{~m}$ were part of the high-altitude group.

\section{Methodology}

\section{Study design}

A cross-sectional analysis of the differences in spirometric parameters was carried out in two populations of Kichwa natives from Ecuador living at two different elevations.

\section{Setting}

This study was carried out in Ecuador in two geographically different areas, the Andes and the Amazon Basin. The research work began in January 2017 and concluded in August 2019. 
Ecuador with an area of more than $283,000 \mathrm{Km} 2$ is the smallest country in the Andean mountainous region in South America. The country is divided into 4 geographical regions, the coast, the highlands, the Amazon region, and the Galapagos Islands. The political division encloses 24 provinces, 10 from the highlands, 7 from the coast, 6 from the Amazon region and 1 from the insular region of Galapagos. Every province has several political divisions called cantons and they are comparable to cities elsewhere. The country has 141 cantons at low altitude, 28 at moderate altitude, 41 at high altitude and 11 at very high altitude. Limoncocha is located at low altitude while Oyacachi is located at very high altitude (Figure 1).

\section{Participants}

The study was carried out with the voluntary participation of 71 members of the Oyacachi community (highaltitude group) located at 3,800 m of elevation and 76 people from Limoncocha (low-altitude control group) located at $230 \mathrm{~m}$ of altitude. All the participants who voluntarily agreed are members of the Kiwcha indigenous group in Ecuador

\section{Inclusion criteria}

Healthy volunteers of both sexes between the ages of 21 and 75 who were born and currently reside in Oyacachi(high-altitude group) and Limoncocha (low -altitude control group).

\section{Exclusion criteria}

Volunteers under 21 years of age, born in another community and who do not normally reside in the parishes were excluded from the study, in addition to those with a history of acute coronary syndrome, acute retinal detachment, aortic aneurysm, endocranial hypertension, and pneumothorax less than one month.

\section{Variables and outcomes}

Sociodemographic variables such as age, sex, place of residence was recorded. General anthropometric measurements including weight, height and BMI were obtained. The following spirometry parameters: FEV ${ }_{1}$, FVC, FEF25-75\% and PEF were included according to predicted values for reference population, meanwhile $\mathrm{FEV}_{1}$ / FVC, known as Tiffeneau-Pinelli index was calculated according to observed values [22].

\section{DNA extraction and analysis of ancestry ratios}

To compare the ancestry of the two populations, a subsample of 47 unrelated individuals (30 Oyacachi vs 17 Limoncocha) was selected. We looked for a subsample among all the individuals to identify those subjects who did not have any first order degree of consanguinity, condition that is based on our laboratory protocol for ancestry analysis. DNA extraction was performed from FTA cards (GE Healthcare) by the Chelex method, then the extracts were diluted to a concentration of $5 \mathrm{ng} / \mathrm{ul}$ using the NanoDrop 2000 UV-Vis spectrophotometer (Thermo Scientific, Waltham, MA)[23]. 46-plex autosomal ancestry informative deletion-insertion markers (46plex AIMs-InDel) were amplified. Fluorescent amplicons were sized by capillary electrophoresis in Pop-7 polymer using a genetic analyzer ABI 3130 (Applied Biosystems, Austin, TX). Alleles were named by the software Genemapper V 3.1 (Life Technologies, Carlsbad, CA) following nomenclature described by Pereira et al, 2012[24]. Taking into account tri-hybrid historic mixture in Ecuador[25-27], Inference of ancestry 
proportions were obtained considering the admixture model with K = 3 (based in Runs consisted of 100,000 burnin steps, followed by 100,000 Markov Chain Monte Carlo (MCMC) using STRUCTURE V2.3.4 software (Pritchard et al., 2000).

\{Citation\}All runs were made without any prior information on the origin of samples and only considered the genetic background for the ancestral continental populations based on reference samples: European, EUR ( $n=$ 158); African, AFR ( $n=105)$; and Native American, NAM ( $n=64)$. Reference genotypes were extracted from the diversity panel of the Human Genome Diversity Project-Center d'Etude du Polymorphisme Humain (HGDPCEPH). The populations selected as comparative groups for Africa were: Angola $(n=1)$, Botswana $(n=4)$, Central African Republic $(n=23)$, Congo $(n=13)$, Kenya $(n=11)$, Lesotho $(n=1)$, Namibia $(n=6)$, Nigeria $(n=$ $22)$, Senegal $(n=22)$ and, South Africa $(n=2)$; for South America: Brazil $(n=22)$, Colombia $(n=7)$, and Mexico ( $n=35)$; and for Europe were: France $(n=52)$, Italy $(n=49)$, Orkney Islands $(n=15)$ and Russia $(n=$ 42).

\section{Exposure}

The chronic exposure to high altitude among indigenous people living in Oyacachi located at 3,800 m.

Outcome

Lung function and spirometry parameters among exposed and not exposed subjects when compared to the spirometric predicted value.

Data sources

Individual-level socio-demographic information, place of residence and past medical history was obtained insitu in both communities. A physical examination including body weight, height and weight was performed. Pulmonary function variables were obtained by performing spirometry in all participants FEV 1 , FVC, FEV1 / FVC, FEF25-75\% and PEF were recorded.

\section{Study size and sample size calculation:}

In terms of the number of patients required to achieve significance the sample size $(n)$ and margin of error $(E)$ were given by the following formula:

$\begin{aligned} x & =Z(c / 100)^{2} r(100-r) \\ n & =N x /\left((N-1) E^{2}+x\right) \\ E & =\operatorname{Sqrt}[(N-n) x / n(N-1)]\end{aligned}$

Where $N$ is the population size ( $n=570$ in Oyacachi and $n=890$ in Limoncocha), $(r)$ is the fraction of predicted responses (50\%), and $Z(c / 100)$ is the critical value for the confidence level $(c)$. The total number of medical and physical evaluation required to achieve significance was 82 for the high altitude group and 96 for the lowaltitude control group. The total number of medical and physical evaluations required to achieve statistical significance was 82 for the high-altitude group and 96 for the low-altitude group. Through a non-probability 
convenience-based sampling technique 118 patients (40 men and 78 women) were included in Limoncocha and 95 (39 men and 56 women) for Oyacachi. A sub-group analysis of only those who met the inclusion criteria for spirometry were included within our study.

\section{Data analysis}

Descriptive statistics were used to analyze and visualize differences between the two populations. T-tests were used to analyze differences between continue variables and Chi square test were the association or independence of categorical variables. When the predicted values were less than 5 in any of the categories, Fisher's exact test or Spearman's test were used when the variable had evident asymmetries with histograms prior to the selection of the test. The strength of association between categorical variables was performed using the V-Cramer test.

All statistical analysis accepted significance with a p-value $<0.05$. Calculations were completed using the IBM Corp. Released 2014. IBM SPSS Statistics for Windows, Version 24.0. Armonk, NY: and R Core Team software 2018 version 3.5.1. Cartography was generated using QGIS Development Team 2.8 and all the references were managed using the open source software Zotero 5.0.85

\section{DNA extraction and analysis of ancestry ratios}

To compare the ancestry of the two populations, a subsample of 47 unrelated individuals (30 Oyacachi vs 17 Limoncocha) was selected. We looked for a subsample among all the individuals to identify those subjects who did not have any first order degree of consanguinity, condition that is based on our laboratory protocol for ancestry analysis. DNA extraction was performed from FTA cards (GE Healthcare) by the Chelex method, then the extracts were diluted to a concentration of $5 \mathrm{ng} / \mathrm{ul}$ using the NanoDrop $2000 \mathrm{UV}$-Vis spectrophotometer (Thermo Scientific, Waltham, MA)[23]. 46-plex autosomal ancestry informative deletion-insertion markers (46plex AIMs-InDel) were amplified. Fluorescent amplicons were sized by capillary electrophoresis in Pop-7 polymer using a genetic analyzer ABI 3130 (Applied Biosystems, Austin, TX). Alleles were named by the software Genemapper V 3.1 (Life Technologies, Carlsbad, CA) following nomenclature described by Pereira et al, 2012[24]. Taking into account tri-hybrid historic mixture in Ecuador[25-27], Inference of ancestry proportions were obtained considering the admixture model with $\mathrm{K}=3$ (based in Runs consisted of 100,000 burnin steps, followed by 100,000 Markov Chain Monte Carlo (MCMC) using STRUCTURE V2.3.4 software[28].

All runs were made without any prior information on the origin of samples and only considered the genetic background for the ancestral continental populations based on reference samples: European, EUR $(n=158)$; African, AFR $(n=105)$; and Native American, NAM $(n=64)$. Reference genotypes were extracted from the diversity panel of the Human Genome Diversity Project-Center d'Etude du Polymorphisme Humain (HGDPCEPH). The populations selected as comparative groups for Africa were: Angola $(n=1)$, Botswana $(n=4)$, Central African Republic $(n=23)$, Congo $(n=13)$, Kenya $(n=11)$, Lesotho $(n=1)$, Namibia $(n=6)$, Nigeria $(n=$ $22)$, Senegal $(n=22)$ and, South Africa $(n=2)$; for South America: Brazil $(n=22)$, Colombia $(n=7)$, and Mexico $(n=35)$; and for Europe were: France $(n=52)$, Italy $(n=49)$, Orkney Islands $(n=15)$ and Russia $(n=$ 42).

\section{Ethical consideration}


A full ethical approval was obtained (\#MED.EOP.17.01) thought out the Universidad de las Americas bioethics committee (CEISH). All patients voluntarily signed an informed consent. For people who could not read or write, an official community translator and a family member capable of understanding what was described in the document were used to explain the entire context of the project and ensure that there were no doubts about it. To protect the identity and autonomy of patients, all personal information was coded to ensure anonymity

\section{Results}

We included 213 patients from both communities, $69 \%(n=118)$ were from Limoncocha and $31 \%(n=95)$ from Oyacachi. The spirometry subgroup included 147 patients, $52 \%(n=76)$ from the low altitude group and $48 \%(n=71)$ from the high altitude group.

Age and sex differences

Within our cohort, women were one year younger $(36.5 \mathrm{y} / 0)$ than men $(37.5 \mathrm{y} / 0)$, while within sex, those living at low altitude were on average of $38 \mathrm{y} / 0$, and those from the high altitude group were $35 \mathrm{y} / 0$, none of these differences were statistically significant (Table 1).

Men living at low altitude where on average 7 years older than men living at high altitude nevertheless, this difference was not significant.

Weight, height, and BMI

In relation to weight, women from the low altitude location were on average $5 \%$ heavier than those women living at high altitude (p: 0.035), while low altitude men were $8.5 \%$ heavier than their high altitude counterpart ( $p<0.001$ ) In terms of height, both men and women had an average height of $151 \mathrm{~cm}$ and $161 \mathrm{~cm}$ respectively, having no differences within groups (Table 1).

[insert Table 1 here] 
Table 1

Sociodemographic, anthropometric and risk factors analysis from the low and high cohorts.

\begin{tabular}{|c|c|c|c|c|c|c|c|c|c|}
\hline & & \multicolumn{4}{|l|}{ Female } & \multicolumn{4}{|l|}{ Male } \\
\hline & & $\begin{array}{l}\text { Low } \\
\text { altitude }\end{array}$ & $\begin{array}{l}\text { High } \\
\text { altitude }\end{array}$ & $\begin{array}{l}\text { (\%) } \\
\text { Diff }\end{array}$ & Sig. & $\begin{array}{l}\text { Low } \\
\text { altitude }\end{array}$ & $\begin{array}{l}\text { High } \\
\text { altitude }\end{array}$ & (\%) Diff & Sig. \\
\hline \multicolumn{2}{|l|}{ Age (mean) } & $\begin{array}{l}38.0 \\
(28.0- \\
48.0)\end{array}$ & $\begin{array}{l}35.0 \\
(30.0- \\
41.0)\end{array}$ & $3.00 \%$ & 0.596 & $\begin{array}{l}41.0 \\
(29.0- \\
50.0)\end{array}$ & $\begin{array}{l}34.0 \\
(27.0- \\
52.0)\end{array}$ & $4.33 \%$ & 0.319 \\
\hline \multirow[t]{3}{*}{$\begin{array}{l}\text { Age } \\
\text { categories }\end{array}$} & $\begin{array}{l}\text { Young } \\
\text { Adult }\end{array}$ & $\begin{array}{l}28 \\
(71.8)\end{array}$ & $\begin{array}{l}33 \\
(80.5)\end{array}$ & $16.40 \%$ & 0.641 & $\begin{array}{l}23 \\
(62.2)\end{array}$ & $\begin{array}{l}22 \\
(73.3)\end{array}$ & $4.44 \%$ & 0.348 \\
\hline & Adult & $\begin{array}{l}10 \\
(25.6)\end{array}$ & $\begin{array}{l}7 \\
(17.1)\end{array}$ & $35.29 \%$ & 0.641 & $\begin{array}{l}12 \\
(32.4)\end{array}$ & $\begin{array}{l}8 \\
(26.7)\end{array}$ & $40.00 \%$ & 0.348 \\
\hline & Elderly & $1(2.6)$ & $1(2.4)$ & $0.00 \%$ & 0.641 & $2(5.4)$ & $0(0.0)$ & & 0.348 \\
\hline \multicolumn{2}{|c|}{$\begin{array}{l}\text { Weight (Kg) - median } \\
\text { (IQR) }\end{array}$} & $\begin{array}{l}64.0 \\
(57.0- \\
75.0)\end{array}$ & $\begin{array}{l}59.0 \\
(55.0- \\
66.0)\end{array}$ & $5.00 \%$ & 0.035 & $\begin{array}{l}73.0 \\
(66.0- \\
80.0)\end{array}$ & $\begin{array}{l}64.5 \\
(60.0- \\
67.5)\end{array}$ & $8.50 \%$ & 0.001 \\
\hline \multicolumn{2}{|c|}{ Height $(\mathrm{cm})(\mathrm{m} \pm \mathrm{SD})$} & $\begin{array}{l}1.51 \\
(0.05)\end{array}$ & $\begin{array}{l}1.51 \\
(0.06)\end{array}$ & $0.00 \%$ & 0.676 & $\begin{array}{l}1.61 \\
(0.06)\end{array}$ & $\begin{array}{l}1.61 \\
(0.05)\end{array}$ & $0.00 \%$ & 0.859 \\
\hline \multicolumn{2}{|c|}{ BMI - median (IQR) } & $\begin{array}{l}28.2 \\
(25.0- \\
31.4)\end{array}$ & $\begin{array}{l}26.5 \\
(24.0- \\
27.6)\end{array}$ & $1.70 \%$ & 0.015 & $\begin{array}{l}27.6 \\
(25.8- \\
30.0)\end{array}$ & $\begin{array}{l}24.8 \\
(23.2- \\
26.0)\end{array}$ & $2.80 \%$ & 0.041 \\
\hline \multirow[t]{6}{*}{$\begin{array}{l}\text { BMI } \\
\text { categories }\end{array}$} & $\begin{array}{l}\text { Under } \\
\text { Weight }\end{array}$ & $0(0.0)$ & $0(0.0)$ & & 0.048 & $0(0.0)$ & $0(0.0)$ & & 0 \\
\hline & Normal & $\begin{array}{l}9 \\
(23.1)\end{array}$ & $\begin{array}{l}13 \\
(31.7)\end{array}$ & $36.36 \%$ & 0.048 & $\begin{array}{l}4 \\
(10.8)\end{array}$ & $\begin{array}{l}16 \\
(57.1)\end{array}$ & $120.00 \%$ & 0.001 \\
\hline & $\begin{array}{l}\text { Over } \\
\text { Weight }\end{array}$ & $\begin{array}{l}17 \\
(43.6)\end{array}$ & $\begin{array}{l}23 \\
(56.1)\end{array}$ & $30.00 \%$ & 0.048 & $\begin{array}{l}23 \\
(62.2)\end{array}$ & $\begin{array}{l}11 \\
(39.3)\end{array}$ & $70.59 \%$ & 0.001 \\
\hline & Obesity & $\begin{array}{l}7 \\
(17.9)\end{array}$ & $\begin{array}{l}5 \\
(12.2)\end{array}$ & $33.33 \%$ & 0.048 & $\begin{array}{l}7 \\
(18.9)\end{array}$ & $1(3.6)$ & $150.00 \%$ & 0.001 \\
\hline & $\begin{array}{l}\text { Extreme } \\
\text { Obesity }\end{array}$ & $\begin{array}{l}6 \\
(15.4)\end{array}$ & $0(0.0)$ & & 0.048 & $3(8.1)$ & $0(0.0)$ & & 0.001 \\
\hline & Total & $\begin{array}{l}39 \\
(100.0)\end{array}$ & $\begin{array}{l}41 \\
(100.0)\end{array}$ & $5.00 \%$ & 0.048 & $\begin{array}{l}37 \\
(100.0)\end{array}$ & $\begin{array}{l}28 \\
(100.0)\end{array}$ & $27.69 \%$ & 0.034 \\
\hline \multirow[t]{3}{*}{ Smoking } & Yes & $0(0.0)$ & $2(4.9)$ & & 0.162 & $0(0.0)$ & $\begin{array}{l}4 \\
(13.3)\end{array}$ & & 0.036 \\
\hline & No & $\begin{array}{l}39 \\
(100.0)\end{array}$ & $\begin{array}{l}39 \\
(95.1)\end{array}$ & $0.00 \%$ & 0.162 & $\begin{array}{l}37 \\
(100.0)\end{array}$ & $\begin{array}{l}26 \\
(86.7)\end{array}$ & $34.92 \%$ & 0.036 \\
\hline & Total & $\begin{array}{l}39 \\
(100.0)\end{array}$ & $\begin{array}{l}41 \\
(100.0)\end{array}$ & $5.00 \%$ & 0.162 & $\begin{array}{l}37 \\
(100.0)\end{array}$ & $\begin{array}{l}30 \\
(100.0)\end{array}$ & $20.90 \%$ & 0.036 \\
\hline $\begin{array}{l}\text { Lung } \\
\text { Disease }\end{array}$ & Yes & $0(0.0)$ & $3(7.3)$ & & 0.085 & $0(0.0)$ & $\begin{array}{l}4 \\
(13.3)\end{array}$ & & 0.036 \\
\hline
\end{tabular}




\begin{tabular}{|lllllllll|}
\hline & \multicolumn{1}{c|}{ Memale } & \multicolumn{7}{c|}{} \\
\hline No & 39 & 38 & $2.60 \%$ & 0.085 & 37 & 26 & $34.92 \%$ & 0.036 \\
& $(100.0)$ & $(92.7)$ & & & $(100.0)$ & $(86.7)$ & & \\
\hline Total & 39 & 41 & $5.00 \%$ & 0.085 & 37 & 30 & $20.90 \%$ & 0.036 \\
& $(100.0)$ & $(100.0)$ & & & $(100.0)$ & $(100.0)$ & & \\
\hline
\end{tabular}

Measured Spirometric results

The high altitude group have a greater FVC and the $\mathrm{FEV}_{1}$, nevertheless, these differences are not significant. The $\mathrm{FEV}_{1} / \mathrm{FVC}$ ratio was inferior at the high altitude group as well as the forced expiratory flow measurements (Table 2).

Table 2

Measured spirometric values between low and high altitude locations

\begin{tabular}{|c|c|c|c|c|c|}
\hline Indicator & Sex & Low Altitude & High Altitude & Mean Differences & Sig. \\
\hline \multirow[t]{2}{*}{ FVC (L) } & Women & 2.6187 & 2.939 & -0.3203 & 0.789 \\
\hline & Men & 3.5362 & 3.957 & -0.4208 & 0.720 \\
\hline \multirow[t]{2}{*}{$\mathrm{FEV}_{1}(\mathrm{~L})$} & Women & 2.5541 & 2.7251 & -0.171 & 0.794 \\
\hline & Men & 3.3505 & 3.602 & -0.2515 & 0.396 \\
\hline \multirow[t]{2}{*}{$\mathrm{FEV}_{1} / \mathrm{FVC}$ ratio } & Women & 95.4385 & 92.761 & 2.6775 & 0.354 \\
\hline & Men & 94.927 & 91.3533 & 3.5737 & 0.391 \\
\hline \multirow[t]{2}{*}{ FEF25-75\% } & Women & 3.9028 & 3.9478 & -0.045 & 0.781 \\
\hline & Men & 4.7384 & 4.5457 & 0.1927 & 0.017 \\
\hline \multirow[t]{2}{*}{ FEF25-75\% - 85\% } & Women & 1.8954 & 1.7346 & 0.1608 & 0.536 \\
\hline & Men & 2.4084 & 1.862 & 0.5464 & 0.008 \\
\hline \multirow[t]{2}{*}{ PEF L/s } & Women & 5.6669 & 5.8726 & -0.2057 & 0.655 \\
\hline & Men & 7.8292 & 7.8143 & 0.0149 & 0.906 \\
\hline \multicolumn{6}{|c|}{$\begin{array}{l}\text { FVC (forced vital capacity), Forced expiratory volume in } 1 \text { second (FEV1) ml, Forced vital capacity ( Liters), } \\
\text { Forced expiratory volume in } 1 \text { second (FEV1) Liters, The FEV1/FVC ratio, also called Tiffeneau-Pinelli } \\
\text { index) \%, Forced expiratory flow at } 25-75 \% \text { of forced vital capacity (FVC) (FEF25-75\%) (Liters/sec), Forced } \\
\text { expiratory flow at } 25-75 \% \text { of forced vital capacity (FVC) (FEF25-75\% - 85\%) Liters/ sec, Peak Expiratory } \\
\text { Flow (L/s), Body mass index (BMI) (kg/m2) }\end{array}$} \\
\hline
\end{tabular}

Predicted Spirometric results

The predicted values demonstrate that high altitude dwellers have greater FVC for both men and women. Also, when compared to the predicted values, the FEV1 was greater for both sexes although only significant among women (Table 3). 
Table 3

Predicted Spirometry values according to sex by altitude

\begin{tabular}{|c|c|c|c|c|c|c|c|c|}
\hline & Female & & & & Male & & & \\
\hline Variables & $\begin{array}{l}\text { Low } \\
\text { altitude }\end{array}$ & $\begin{array}{l}\text { High } \\
\text { altitude }\end{array}$ & $\begin{array}{l}\text { (\%) } \\
\text { Diff }\end{array}$ & Sig. & $\begin{array}{l}\text { Low } \\
\text { altitude }\end{array}$ & $\begin{array}{l}\text { High } \\
\text { altitude }\end{array}$ & $\begin{array}{l}\text { (\%) } \\
\text { Diff }\end{array}$ & Sig. \\
\hline $\mathrm{FVC} \mathrm{(L)}$ & $\begin{array}{l}93.51 \\
(15.40)\end{array}$ & $\begin{array}{c}108.93 \\
(19.70)\end{array}$ & $15.23 \%$ & 0.001 & $\begin{array}{l}92.24 \\
(15.16)\end{array}$ & $\begin{array}{l}100.43 \\
(15.56)\end{array}$ & $8.50 \%$ & 0.033 \\
\hline FEV1 (L) & $\begin{array}{l}101.36 \\
(23.03)\end{array}$ & $\begin{array}{l}115.15 \\
(14.92)\end{array}$ & $12.74 \%$ & 0.002 & $\begin{array}{l}104.32 \\
(16.48)\end{array}$ & $\begin{array}{l}105.00 \\
(24.02)\end{array}$ & $0.65 \%$ & 0.892 \\
\hline $\begin{array}{l}\text { FEV1/FVC - } \\
\text { (IQR) }\end{array}$ & $\begin{array}{l}1.18 \\
(1.11- \\
1.23)\end{array}$ & $\begin{array}{l}1.14 \\
(1.10- \\
1.18)\end{array}$ & 4.0 & 0.029 & $\begin{array}{l}1.20 \\
(1.15- \\
1.24)\end{array}$ & $\begin{array}{l}1.14 \\
(1.10- \\
1.18)\end{array}$ & 6.0 & 0.003 \\
\hline $\begin{array}{l}\text { FEF 25- } \\
75 \%(\mathrm{~L} / \mathrm{s})\end{array}$ & $\begin{array}{l}110.32 \\
(26.75)\end{array}$ & $\begin{array}{l}112.54 \\
(24.88)\end{array}$ & $1.99 \%$ & 0.703 & $\begin{array}{l}114.25 \\
(23.45)\end{array}$ & $\begin{array}{l}109.07 \\
(21.65)\end{array}$ & $4.64 \%$ & 0.358 \\
\hline PEFR (L/s) & $\begin{array}{l}94.00 \\
(17.46)\end{array}$ & $\begin{array}{l}97.17 \\
(18.32)\end{array}$ & $3.31 \%$ & 0.431 & $\begin{array}{l}95.46 \\
(16.60)\end{array}$ & $\begin{array}{l}96.03 \\
(26.26)\end{array}$ & $0.60 \%$ & 0.914 \\
\hline
\end{tabular}

The maximum flow rate generated during a forceful exhalation (PEFR) was also greater among highlanders when compared to the predicted values, nevertheless, the differences where not significant (Fig. 2).

\section{Discussion}

In our study we found that high altitude dwellers have greater pulmonary capacities, similar to those results published by other authors[10,16-18]. We found that people living at high altitudes have a higher forced vital capacity than those living at low altitudes, and this difference is statistically significant for both men and women (Fig. 2).

Having greater FVC is probably linked to anatomical changes that have evolve from centuries of adaptation[6, 29-31]. Some of these evolutionary anatomical adaptations (wider and deeper chest) confer these populations with larger lungs, which result in a greater capacity to accommodate more air. Wider chest and improved pulmonary performance go along with stronger expiration rates. The $F E V_{1}$, was also higher in those living at high altitudes, nevertheless, greater lung capacity was also related with slightly lower $\mathrm{FEV}_{1} / \mathrm{FVC}$ ratio.

These findings have even correlated with similar findings reported in people who rapidly ascend to significant elevations. Sharma et al., in 2007 found that at 3,450m FVC had an initial increase of $9 \%$ within the first 24 hours followed by a significant decrease in the $\mathrm{FVC}$ as well as in $\mathrm{FEF}_{1}$ and within the maximal voluntary ventilation. At $5,350 \mathrm{~m}$ there was a $21 \%$ increase in FVC within the first 48 hours, with a subsequent decrease as with the other measured values[32]. In relation to age, it appears that the findings on lung capacity are maintained throughout life. Cid-Juarez et al. in 2019 found that inspiratory capacity and forced vital capacity among healthy individuals between 9 and 81 years of age residing above 2,240 m elevation presented an enviable increase in these parameters, with the highest peak from 9 to 20 years of age[33]. Another interesting study this time investigating the effects of acute hypoxia on respiratory parameters among young subjects 
demonstrated that[34]. The "Young Everest study" concluded that at 3,500 $\mathrm{m}$ above sea level, lung function remained within $7 \%$ of baseline among children. They also observed that rapid exposure to high altitude was associated with a significant reduction (up to $23 \%$ ) in the overall $\mathrm{FVC}$ and $16 \%$ in $\mathrm{FEV}_{1}$ in children[34].

Comparing the spirometric values against predictive values is a more fair comparison. The results of these analysis is to observe how their lungs are performing against of what we would predicted for the same sex, age, weight and height[35, 36]. In Ecuador we do not have defined equations to obtain predetermined pulmonary function values. According to the Third National Health and Nutrition Examination Survey of the American Union (NHANES III), in these cases where data is not locally available, the equations to be used are those coming from their closest peers[37]. In Latin America, spirometric studies are relatively scarce. One of the most important projects related to the subject is the Latin American Project for Research in Pulmonary Obstruction (PLATINO). This group found that the predicted values at the pulmonary function level in the Latin American population are like the American population of Mexican origin within the NHANES III study[38]. A study has recently been published in which predictive equations have been performed for each spirometric variable among children living at moderate and high altitude in Colombia, which could be useful for further analysis among children[39].

In this sense, scarce literature is available within the Andean region, nevertheless, Lopez et al., have published an interesting study about the references values among highlanders from south America[17]. They observed higher predictive values in populations living at high altitudes when compared to those predicted values from people located at sea level[17]. Similar results were published by Firoi et al., conducted a study in Central Asia where he compared the Kirghiz population with their medium and low altitude counterparts and observed that $\mathrm{FEV}_{1}$ and FVC were lower in the high altitude populations [40].

The objectives of our study were not to identify etiologic factors of chronic obstructive pulmonary disease (COPD), nonetheless with the few patients who had a previous pathologic history we were able to find that both populations had a restrictive pattern in $12.9 \%$ with a predominance in the low altitude group. In other high altitude regions, COPD seems to be a significant health problem. In Yanfei Guo et al., publication, COPD in residents living at 2,100-4,700 $\mathrm{m}$ above sea level, at least $8.2 \%$ reported pulmonary patterns compatible with COPD and concluded that the prevalence of COPD was inversely related to altitude, a similar conclusion that the one reported by Laniado et al., in $2012[41,42]$.

In relation to the presence of smoking or any history of pulmonary disease, we found that women and men at high altitude smoke more than those living at lower altitude (Table 1). One study tried to address the implications of smoking in subjects who reside but were not necessarily born at high altitude. This 5-year prospective cohort study sought to monitor lung function among individuals exposed to chronic intermittent hypoxia $(\mathrm{CIH})$ working in high altitude mines[43]. They found an annual small but significant decrease in FVC and $\mathrm{FEV}_{1}$ among those intermittently exposed to hypobaric hypoxia. They reported that the group of smokers have an earlier deterioration of the pulmonary function than then non-smokers [43].

Our results are the first one in using two genotype-controlled natives living at low and high altitude locations. To our knowledge, this is the first study of this kind and the results of this study can be primarily used for 
further explore the relationship between chronic hypoxia exposure and pulmonary function among adapted and non-adapted subjects living in the Andes.

\section{Conclusion}

Residents of Oyacachi had greater lung capacity than their peers from the Limoncocha, indicating a greater pulmonary capacity, physiologically plausible according to published literature. When analyzing the spirometric patterns obtained in these populations, it was evident that no person had an obstructive pattern, while on the other hand, the restrictive pattern appeared in Limoncocha and Oyacachi populations in $12.9 \%$ although it is clear that there is a predominance of this in the individuals belonging to Limoncocha.

\section{Limitations}

The main limitation is that, despite obtaining a significant sample size to carry out this study, not all the population belonging to these indigenous communities that met the inclusion criteria were willing to participate. So, even if it is a small probability, it cannot rule out that the inclusion of the data corresponding to those people who did not participate could produce variations in our results or even alters our interpretation. Another potential weakness is the gender asymmetry in the sample because men were a lower number of participants than women. Another limitation is the fact that we do not have local spirometry equations for the correct analysis of the predictive values among highlanders in Ecuador.

\section{Declarations}

\section{Ethics approval and consent to participate}

All data were collected from the patient's medical records after obtaining written informed consent. The study was approved by the Hospital Eugenio Espejo review board. All data was anonymized, and all identifiable information and biological samples were stored according to the local guidelines.

\section{Data availability}

The datasets generated and analysed during the current study are available in the following link https://github.com/covid19ec/Spirometry

\section{Consent to publish}

Written informed consent was obtained from every patient in the study.

\section{Author Disclosure Statement}

The authors declare no conflicts of interest

\section{Funding}

This work: design of the study and collection, analysis, interpretation of data, and writing, did not receive financial support of any kind except for the publication fee paid in full by Universidad de las Americas, Quito, 
Ecuador.

\section{Authors' Contributions}

EOP was fully responsible for the conceptualization, data collection and elaboration of the study. EOP, SE, LGB and JM participated in drafting the manuscript equally and are fully responsible for it. SE, JM, DD and IO visited indigenous communities and apply the spirometry tests. KSR, JSIC and EOP contributed with the data collection and the construction of figures and tables. EOP, MC, EV, and GV contributed with the descriptive statistical analysis and the discussion section of the manuscript. GB was fully responsible for the ancestry analysis and EOP, GV and MC critically reviewed the entire manuscript and produced several comments prior to the submission.

All authors have read and approved the manuscript.

Acknowledgement: The authors thank the patients and their families who contributed to the completion of this study. We also want to express our gratitude to the Oyacachi health sub-center and the Limoncocha health sub-center staffs for allowing us to use their facilities.

\section{References}

1. Pasha MQ, Newman JH. High-altitude disorders: pulmonary hypertension: pulmonary vascular disease: the global perspective. Chest. 2010;137:13S-19S.

2. Miranda JJ, Bernabe-Ortiz A, Gilman RH, Smeeth L, Malaga G, Wise RA, et al. Multimorbidity at sea level and high-altitude urban and rural settings: The CRONICAS Cohort Study. J Comorbidity. 2019;9:2235042X19875297.

3. Milledge J. Hypobaria: High Altitude, Aviation Physiology, and Medicine. Cotes' Lung Funct. 2020;:61537.

4. Ortiz-Prado E, Dunn JF, Vasconez J, Castillo D, Viscor G. Partial pressure of oxygen in the human body: a general review. Am J Blood Res. 2019;9:1.

5. Azad P, Stobdan T, Zhou D, Hartley I, Akbari A, Bafna V, et al. High-altitude adaptation in humans: from genomics to integrative physiology. J Mol Med. 2017;95:1269-82.

6. Talaminos-Barroso A, Roa-Romero LM, Ortega-Ruiz F, Cejudo-Ramos P, Márquez-Martín E, Reina-Tosina J. Effects of genetics and altitude on lung function. Clin Respir J. 2020;n/a n/a. doi:https://doi.org/10.1111/crj.13300.

7. West JB, Schoene RB, Milledge JS, Ward MP. High altitude medicine and physiology. Fourth Edition. London: Hodder Arnold London; 2007. http://www.jrnms.com/wp-content/uploads/2014/05/JRNMS-951-40-43.pdf. Accessed 12 Sep 2016.

8. Naeije R. Physiological adaptation of the cardiovascular system to high altitude. Prog Cardiovasc Dis. 2010;52:456-66.

9. Beall CM. A comparison of chest morphology in high altitude Asian and Andean populations. Hum Biol. 1982;:145-63. 
10. Brutsaert TD, Soria R, Caceres E, Spielvogel H, Haas JD. Effect of developmental and ancestral high altitude exposure on chest morphology and pulmonary function in Andean and European/North American natives. Am J Hum Biol Off J Hum Biol Assoc. 1999;11:383-95.

11. Xi H, Chen Z, Li W, Wen Y, Zhang H, Xiao Y, et al. Chest circumference and sitting height among children and adolescents from Lhasa, Tibet compared to other high altitude populations. Am J Hum Biol. 2016;28:197-202.

12. Brutsaert TD, Soria R, Caceres E, Spielvogel H, Haas JD. Effect of developmental and ancestral high altitude exposure on chest morphology and pulmonary function in Andean and European/North American natives. Am J Hum Biol. 1999;11:383-95.

13. Beall CM, Strohl KP, Blangero J, Williams-Blangero S, Almasy LA, Decker MJ, et al. Ventilation and hypoxic ventilatory response of Tibetan and Aymara high altitude natives. Am J Phys Anthropol Off Publ Am Assoc Phys Anthropol. 1997;104:427-47.

14. Zhuang J, Droma T, Sun S, Janes C, McCullough RE, McCullough RG, et al. Hypoxic ventilatory responsiveness in Tibetan compared with Han residents of 3,658 m. J Appl Physiol. 1993;74:303-11.

15. Sato M, Severinghaus JW, Powell FL, Xu F-D, Spellman Jr MJ. Augmented hypoxic ventilatory response in men at altitude. J Appl Physiol. 1992;73:101-7.

16. Kiyamu M, Elías G, León-Velarde F, Rivera-Chira M, Brutsaert TD. Aerobic capacity of P eruvian Q uechua: a test of the developmental adaptation hypothesis. Am J Phys Anthropol. 2015;156:363-73.

17. López Jové OR, Arce SC, Chávez RW, Alaniz A, Lancellotti D, Chiapella MN, et al. Spirometry reference values for an andean high-altitude population. Respir Physiol Neurobiol. 2018;247:133-9.

18. Weitz CA, Garruto RM, Chin C-T. Larger FVC and FEV 1 among Tibetans compared to Han born and raised at high altitude. Am J Phys Anthropol. 2016;159:244-55.

19. Compte-Torrero L, de Maglia JB, de Diego-Damiá A, Gómez-Pérez L, Ramírez-Galleymore P, PerpiñáTordera M. Changes in spirometric parameters and arterial oxygen saturation during a mountain ascent to over 3000 meters. Arch Bronconeumol Engl Ed. 2005;41:547-52.

20. Cremona G, Asnaghi R, Baderna P, Brunetto A, Brutsaert T, Cavallaro C, et al. Pulmonary extravascular fluid accumulation in recreational climbers: a prospective study. The Lancet. 2002;359:303-9.

21. Weitz CA, Garruto RM, Chin C-T, Liu J-C, Liu R-L, He X. Lung function of Han Chinese born and raised near sea level and at high altitude in Western China. Am J Hum Biol Off J Hum Biol Counc. 2002;14:494-510.

22. García-Río F, Calle M, Burgos F, Casan P, del Campo F, Galdiz JB, et al. Espirometría. Arch Bronconeumol. 2013;49:388-401.

23. Walsh PS, Metzger DA, Higuchi R. Chelex 100 as a medium for simple extraction of DNA for PCR-based typing from forensic material. Biotechniques. 1991;10:506-13.

24. Pereira R, Phillips C, Pinto N, Santos C, Santos SEB dos, Amorim A, et al. Straightforward Inference of Ancestry and Admixture Proportions through Ancestry-Informative Insertion Deletion Multiplexing. PLoS ONE. 2012;7:e29684.

25. Toscanini U, Gaviria A, Pardo-Seco J, Gómez-Carballa A, Moscoso F, Vela M, et al. The geographic mosaic of Ecuadorian Y-chromosome ancestry. Forensic Sci Int Genet. 2018;33:59-65. 
26. Santangelo R, González-Andrade F, Børsting C, Torroni A, Pereira V, Morling N. Analysis of ancestry informative markers in three main ethnic groups from Ecuador supports a trihybrid origin of Ecuadorians. Forensic Sci Int Genet. 2017;31:29-33.

27. Zambrano AK, Gaviria A, Cobos-Navarrete S, Gruezo C, Rodríguez-Pollit C, Armendáriz-Castillo I, et al. The three-hybrid genetic composition of an Ecuadorian population using AIMs-InDels compared with autosomes, mitochondrial DNA and Y chromosome data. Sci Rep. 2019;9:1-8.

28. Pritchard JK, Stephens M, Rosenberg NA, Donnelly P. Association mapping in structured populations. Am J Hum Genet. 2000;67:170-81.

29. Fiori G, Facchini F, Ismagulov O, Ismagulova A, Tarazona-Santos E, Pettener D. Lung volume, chest size, and hematological variation in low-, medium-, and high-altitude Central Asian populations. Am J Phys Anthropol. 2000;113:47-59.

30. Moore LG. Human genetic adaptation to high altitude. High Alt Med Biol. 2001;2:257-79.

31. Havryk AP(1 2), Gilbert M( 1 ), Burgess KR( 12 ). Spirometry values in Himalayan high altitude residents (Sherpas). Respir Physiol Neurobiol. 2002;132:223-32.

32. Sharma S, Brown B. Spirometry and respiratory muscle function during ascent to higher altitudes. Lung. 2007;185:113-21.

33. Cid-Juárez S, Thirión-Romero I, Torre-Bouscoulet L, Gochicoa-Rangel L, Martínez-Briseño D, HernándezPaniagua IY, et al. Inspiratory Capacity and Vital Capacity of Healthy Subjects 9-81 Years of Age at Moderate-High Altitude. Respir Care. 2019;64:153-60.

34. Scrase E, Laverty A, Gavlak JC, Sonnappa S, Levett DZ, Martin D, et al. The Young Everest Study: effects of hypoxia at high altitude on cardiorespiratory function and general well-being in healthy children. Arch Dis Child. 2009;94:621-6.

35. Schneider A, Gindner L, Tilemann L, Schermer T, Dinant G-J, Meyer FJ, et al. Diagnostic accuracy of spirometry in primary care. BMC Pulm Med. 2009;9:1-10.

36. Venkateshiah SB, loachimescu OC, McCarthy K, Stoller JK. The utility of spirometry in diagnosing pulmonary restriction. Lung. 2008;186:19-25.

37. Pérez-Padilla R, Valdivia G, Muiño A, Victorina López M, Nelly Márquez M, de Oca MM, et al. Valores de referencia espirométrica en 5 grandes ciudades de Latinoamérica para sujetos de 40 o más años de edad. Arch Bronconeumol. 2006;42:317-25.

38. Sood A, Dawson BK, Henkle JQ, Hopkins-Price P, Qualls C. Effect of change of reference standard to NHANES III on interpretation of spirometric 'abnormality.' Int J Chron Obstruct Pulmon Dis. 2007;2:361.

39. Aristizabal-Duque R, Sossa-Briceño MP, Rodriguez-Martinez CE. Development of spirometric reference equations for children living at high altitude. Clin Respir J. 2020;14:1011-7.

40. Fiori G, Facchini F, Ismagulov O, Ismagulova A, Tarazona-Santos E, Pettener D. Lung volume, chest size, and hematological variation in low-, medium-, and high-altitude Central Asian populations. Am J Phys Anthropol Off Publ Am Assoc Phys Anthropol. 2000;113:47-59.

41. Guo Y, Xing Z, Shan G, Janssens J-P, Sun T, Chai D, et al. Prevalence and Risk Factors for COPD at High Altitude: A Large Cross-Sectional Survey of Subjects Living Between 2,100-4,700 m Above Sea Level. Front Med. 2020;7:898. 
42. Laniado-Laborin R, Rendón A, Batiz F, Alcantar-Schramm JM, Bauerle O. High altitude and chronic obstructive pulmonary disease prevalence: a casual or causal correlation? Arch Bronconeumol Engl Ed. 2012;48:156-60.

43. Vinnikov DV. Five-year monitoring of annual pulmonary function decline in individuals exposed to chronic intermittent hypoxia. Ter Arkh. 2012;84:45-8.

Figures

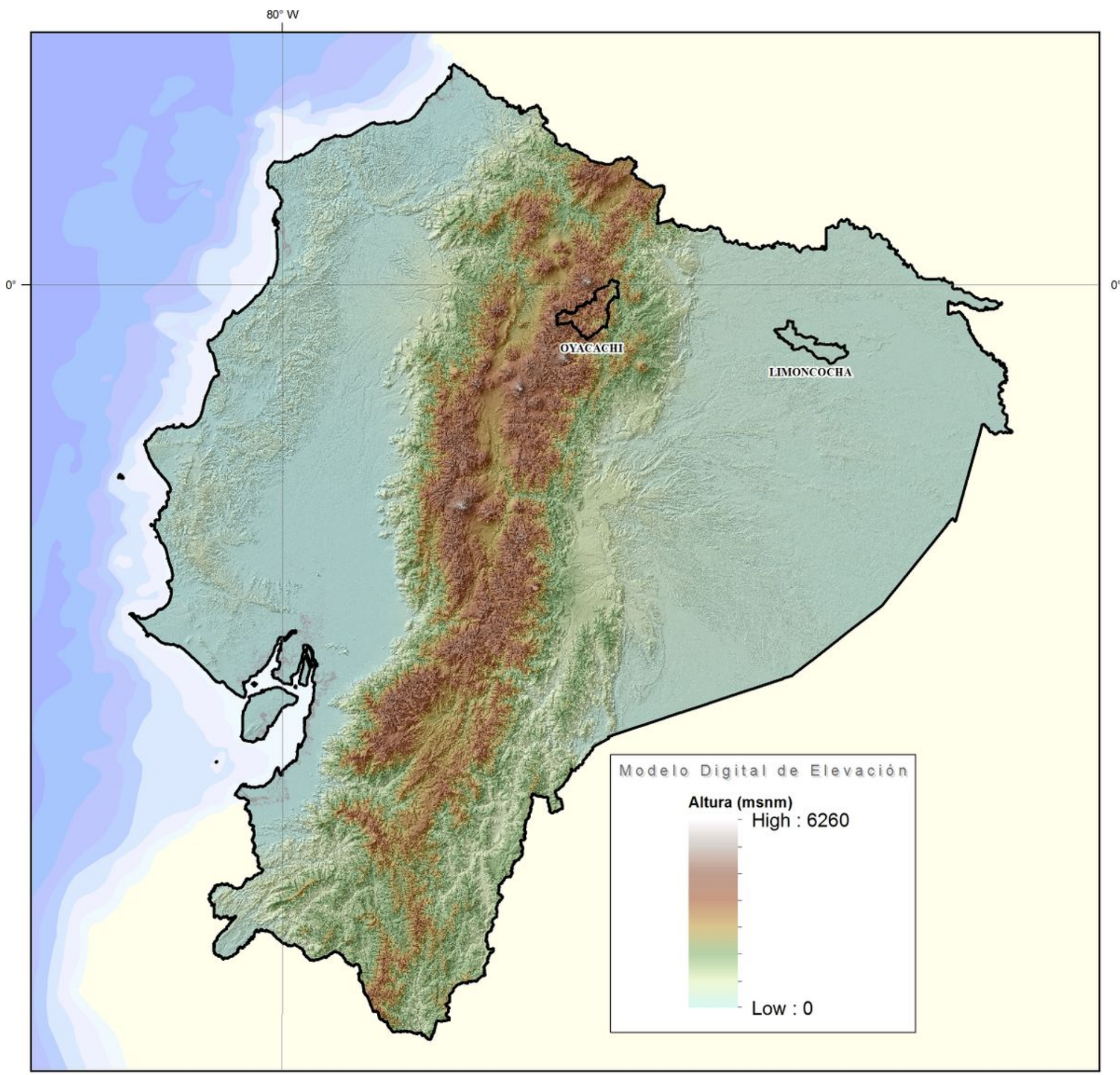

$80^{\circ} \mathrm{W}$

Figure 1 
Topographic map of Ecuador highlighting Limoncocha $(230 \mathrm{~m})$ and Oyacachi $(3,800 \mathrm{~m})$.
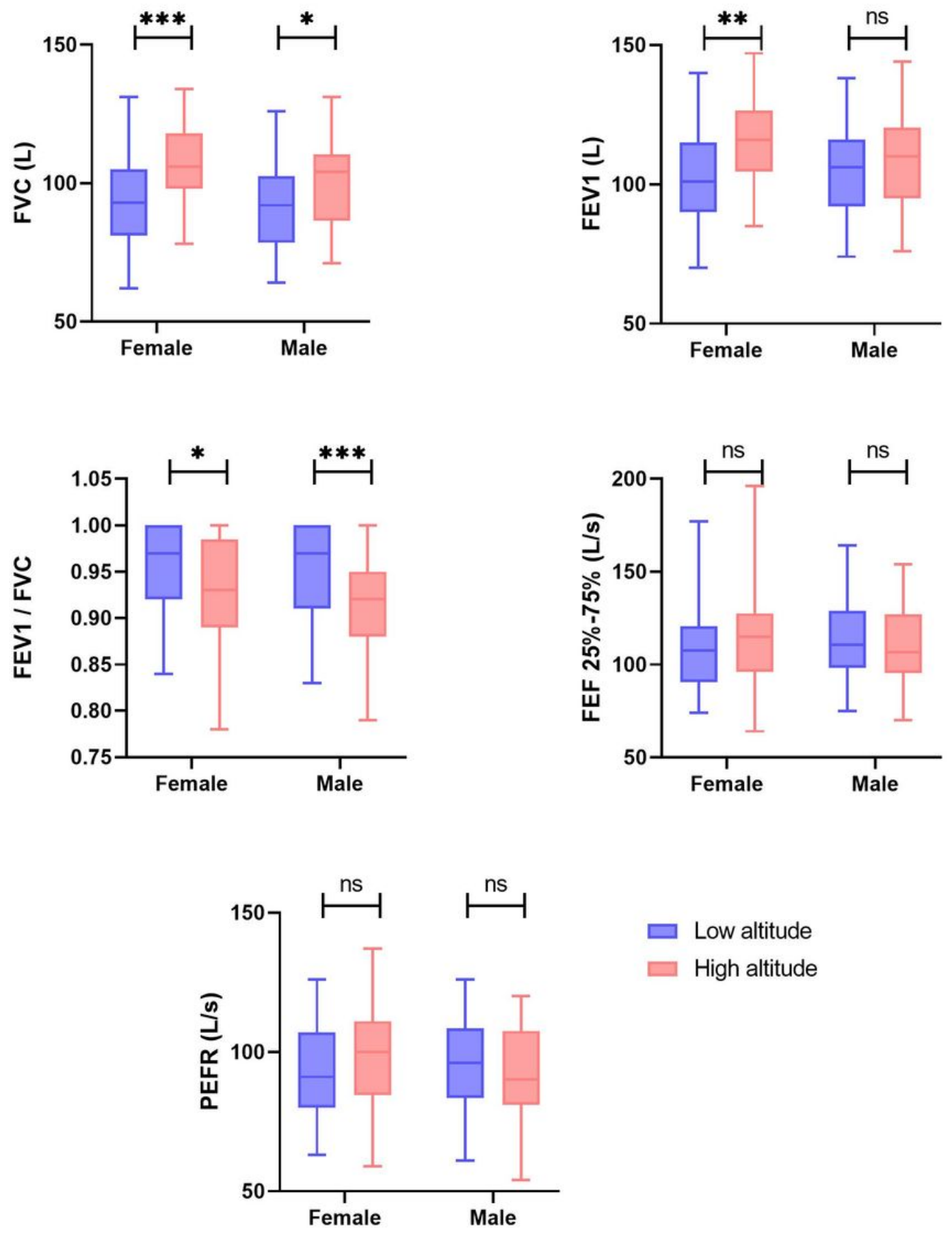

Figure 2

Spirometric values compared to predicted values among low and high altitude dwellers. 